\title{
Tezer Özlü’nün eserlerinde “an”ların işleniş formları ve epifanlar
}

\section{Emine AYAN1}

APA: Ayan E. (2020). Tezer Özlü’nün eserlerinde “an”ların işleniş formları ve epifanlar. RumeliDE Dil ve Edebiyat Araşttrmaları Dergisi, (20), 267-277. DOI: 10.29000/rumelide.791459.

\section{$\ddot{\mathbf{O} z}$}

Kökeni görünme ya da ortaya çıkma anlamındaki Yunanca epiphaneia sözcüğüne dayanan epifan, insan zihninde uyanışlara yol açan anlık olgulara işaret eder. Kökensel anlamı ile ilişkili olarak dinî ve mitolojik bir bağlamı da bulunan sözcük, 19. yüzyılda William Wordsworth, Thomas de Quincey gibi sanatçıların etkisiyle dünyevi olana işaret eden somut bir anlam alanı içerisinde kullanılmaya başlar. 20. yüzyıldan itibaren ise epifanın James Joyce'un yazınsal faaliyeti kapsamında insanın iç dünyasını önceleyen modernist metinlerde sıkça rastlanan bir teknik olarak dikkat çektiği görülür. Edebî bağlamı ile epifan, insan zihninde gerçekleşen anlık uyanışların bir ifadesi olarak anlatıda kurmacaya yön veren anlara karşılık gelir. Batı'daki gelişimine paralel olarak Türk edebiyatında da epifan tekniğinin kullanıldığı eserler söz konusudur. Bu çalışmada edebiyatımızın erken yitirdiği isimlerinden biri olan Tezer Özlü’nün (1943-1986) hayatta iken yayımlanan Eski Bahçe (1978), Çocukluğun Soğuk Geceleri (1980) ve Yaşamın Ucuna Yolculuk (1984) adlı kitaplarındaki “an”ların işleniş formları bağlamında epifanların izi sürülerek bu tekniğin modernist metinlerdeki görünümüne işık tutulacaktır.

Anahtar kelimeler: Epifan, modernist edebiyat, Tezer Özlü, Eski Bahçe, Çocukluğun Soğuk Geceleri, Yaşamın Ucuna Yolculuk

\section{The processing forms of "moment"s and epiphanies in Tezer Ozlu's works}

\begin{abstract}
Epiphany, based on the Greek word epiphaneia which means to appear or emerge, refers to instantaneous phenomena that cause sudden awakenings in the human mind. The word, which has a religious and mythological context in relation to its original meaning, started to be used in a concrete area of meaning in the 19th century, pointing to the worldly, under the influence of artists such as William Wordsworth and Thomas de Quincey. As of the 2oth century, it is seen that the epiphany has attracted attention as a common technique in modernist texts prioritizing the inner world of man within the context of James Joyce's literary activity. Epiphany, with its literary context, refers to the "moments" that direct fiction in the narrative as an expression of instant awakenings in the human mind. In parallel with its development in the West, there are works in which Turkish literature uses epiphany technique. In this study the appearance of epiphany technique in modernist texts will be shed light on with tracing epiphanies in the context of the processing forms of "moment"s in the books published while she was alive called Eski Bahçe (1978), Çocukluğun Soğuk Geceleri (1980) and Yaşamin Ucuna Yolculuk (1984) of Tezer Özlü (1943-1986) who is one of the names that our literature has lost prematurely,
\end{abstract}

Arş. Gör. Dr. Çukurova Üniversitesi, Fen Edebiyat Fakültesi, Türk Dili ve Edebiyatı Bölümü (Adana, Türkiye) eayan333@gmail.com, ORCID ID: 0ooo-0003-2132-5587 [Makale kayıt tarihi: 13.07.2020-kabul tarihi: 20.09.2020; DOI: $10.29000 /$ rumelide.791459] 
Keywords: Epiphany, modernist literature, Tezer Özlü, Eski Bahçe, Çocukluğun Soğuk Geceleri, Yaşamın Ucuna Yolculuk

\section{Giriş}

İnsan yaşamında çarpıcı etki uyandıran anlar şeklinde tanımlanabilecek olan epifan², Yunanca "görünme" ya da "ortaya çıkma" anlamındaki epiphaneia'dan gelir (Ballard, 2012, s. 17). İngilizcede "aniden bir şeyin anlaşıldığı durum" (Longman, 2010, s. 567) olarak kullanılan sözcük, Türkçede "uyanıklık" (TDK, 2005, s. 99) karşılığındaki anıklık3 ile ifade edilir. Epifanın "Tanrıların insan şeklinde yahut başka şekilde maddî olarak görünmesi” (Can, 1970, s. 442); Lodge’un (2013) tanımıyla "tecelli” (s. 177) şeklindeki dinî bağlamı ile Hıristiyan terminolojisinde İsa'nın üç Magi'ye4 gösterilmesine işaret ettiği (s. 177) ve dünyayı aydınlatacak kişinin varlığının onaylandığı o günün 6 Ocak’ta kiliselerde bir şölen biçiminde kutlandığı (Öğretir, 2005, s. 5) bilinir. Mitolojik bağlamında ise epifan, "güneş ve güzel sanatlar tanrısı" (Can, 1970, s. 431) Apollon'un doğduğu yer olan Delos adasına ilkbaharda dönüşü ile tabiatta gerçekleşen coşku ve uyanışı (Can, 1970, s. 58) çağrıştırır.

İngilizcede ilk kez 14. yüzyılda görülen ve 17. yüzyıla değin dinî bağlamı dışında bir kullanım alanına rastlanmayan epifanın, 19. yüzyıldan itibaren Thomas de Quincey, William Wordsworth gibi sanatçıların etkisiyle bir anlam genişlemesine uğradığı (Ballard, 2012, s. 17); 20. yüzyılda ise James Joyce ile birlikte estetik bir düzlemde kurmacaya yön veren anlara işaret eden yazınsal bir kavram olarak belirdiği görülür. Joyce'un İlk gençlik yıllarından itibaren kulağına çalınan konuşmalardan ya da kendi kendine düşündüklerinden hareketle biriktirip kurmaca yapıtlarının içine yerleştirdiği kırk kısa yazı parçasından oluşan anıklıkları (Litz, 1996, s. 9) bulunur. 19. yüzyılın geleneksel kurgu anlayışından ziyade akronolojik bir olay ve zaman anlayışının hâkim olduğu modernist bir kurguyu benimseyen Joyce, epifanı, yayımlatmadan yok ettiği Sanatçının Bir Genç Adam Olarak Portresi’nin ilk biçimi Stephen Hero'da "ister konuşmanın ya da devinimin bayağılığında ister anlığın kendisinin unutulmaz bir evresinde olsun, tinsel bir açılma" (Litz, 1996, s. 10) olarak tanımlar. Buna göre epifan, insanın iç dünyasına ışık tutan anlara işaret eder. Joyce bu anları "tam da insanların en çok saklamaya özen gösterdikleri şeyleri açığa vurdukları -yelde savrulan samanlara benzer- sürçmeler, devinimcikler” (Litz, 1996, s. 9) addeder. Modernist edebiyatın gelişme gösterdiği 20. yüzyılda Joyce'un yanı sıra Geçmiş Zamanın Peşinde (1913-22) adlı uzun soluklu romanında tasarlanmamış hatırlama anlarından söz eden (Öğretir, 2005, s. 13) Proust'un da etkisiyle epifanik kullanımlar yaygınlık kazanmaya başlar.

Estetik düzlemde "bir figürün olay örgüsünün bir kesitinde tetikleyici bir nesne ya da olayın yönlendiriciliğinde yaşadığı aydınlanma anı”nın (Sazyek, 2019, s. 75) ifadesi olan epifan, anlatı kişilerinin yaşamına damga vuran anlık olgulara işaret eder. "Küçük, sıradan ve bilindik görünen olguların insan yaşamında aslında önemli olduğu veya olabileceği gerçeğine dikkat çekme aracı" (Koçsoy, 2018, s. 116) olan bu teknik, değişme/kırılma anlarının anlatı kişisi üzerindeki çarpıcı etkilerini yansitır. Epifanın özü Lodge'un ifadesiyle “an”ın yoğunluğu”na (s. 178) dayanır. Epifan geçmiş ile geleceği bünyesinde barındıran an odaklı bir yaklaşımdır.

\footnotetext{
2 Bu sözcüğe kimi kaynaklarda epifani olarak rastlanmaktadır. Bu makalede İsmail Öğretir’in Edebiyatta Epifan Sherwood Anderson’un Winesburg Ohio'su (2005) adlı kitabında sözcüğe ilişkin kullanımı tercih edilmiştir.

Her ne kadar İsmail Öğretir, Edebiyatta Epifan Sherwood Anderson'un Winesburg Ohio'su (2005) adlı kitabında “epiphany" terimine Türkçede karşılık olarak önerilen "anıklık” sözcügünün yetenek, eğilim vb. anlamlarına gelen "aptitude" terimine daha uygun bir karşllık gibi göründüğü gerekçesiyle terimin içeriğini tam olarak yansıtmadığını (s. 2) ifade etse de James Joyce'un Epiphanies/Anıklkklar (çev. Levent Kavas) adlı kitapta yer alan kırk kısa yazın parçasına 'anıklıklar' adını verdiği (s. 9) bilinmektedir.

4 Hz. isa'nın doğumunu kutlamak için Kudüs'e gelen iranlı müneccimler (https://tureng.com/tr/turkce-ingilizce/magi).
} 
Epifanı kurgunun kritik anlarını tayin eden bir teknik olarak düşünmek mümkündür. Nitekim epifanik anlatımda anlar kurmaca dünyada anlatıya şekil veren düğüm noktaları olarak işlev görür. Kurgusal atmosferde anlatı kişisi düzeyinde gerçekleşen "aydınlanma ânı” (s. 42), Sazyek'in (2013) ifadesiyle “... yeni bir süreç başlatırken aynı zamanda ... bir doruk/dönüm noktası da oluşturur” (s. 42). Dolayısıyla epifan, anlatı kişilerinin üzerinde olumlu ya da olumsuz bağlamda değiştirici/dönüştürücü bir etki uyandırır. Kimi zaman bu etkinin bireyselden evrensele uzanan bir mahiyet arz ettiği görülür. Epifan "bireysel deneyimlerin toplumsal hatta evrensel olana ışık tuttuğu bir öze sahiptir" (Sazyek, 2019, s. 85). Epifanda bu özün yer yer metnin kodlarına işaret eden metaforlar aracılı̆̆ıyla okura iletildiğii; dolayısıyla bu tekniğin metaforik bir yönünün de bulunduğu görülür.

Yüzyıllar boyu birçok şair ve yazarın kullandığı epifan, modernistler tarafından yeni kalıplara dökülerek (Öğretir, 2005, s. iii) kullanılır. 20. yüzyılda dünya düzeninde gerçekleşen değişimler, sanat ve edebiyat dünyasında da yankısını bulur. "Değerlerin altüst olduğu, sekülerleşmenin . . . yayıldığı, iki dünya savaşında milyonlarca insanın yok olduğu ve ekonomik krizlerin yaşandığı” (Öğretir, 2005, s. iii) bu dönemde "yeni düşünceler ve değerlerle birlikte yeni kalıplar, tarzlar ve teknikler sanatın merkezine yerleşir" (Öğretir, 2005, s. iii). Epifan da bütüncül bir gerçekliğin, kronolojik bir olay ve zaman anlayışının hâkim olduğu realist anlatı geleneğinin yerini parçalı bir gerçeklikle örülü akronolojik bir anlatı geleneğine bıraktığı modernist edebiyatta içinde bulunduğu kaosta giderek yabancılaşan, yalnızlaşan ve varoluş bunalımı içinde kıvranan insanın anlık aydınlanmalarla şekillenen dramını dillendirmek için kullanılır. "Realist estetiği aşan, bireyi olanca karmaşıklığı ile yansıtmak isteyen . . . modernist yazarlar" (Apaydın, 2020, s. 142) bu tekniği modern insanın içine düştüğü söz konusu boğucu ortamda yaşamdaki sıradan şeylerin önemine dikkat çekmek ve insanın parıltılı anlar yaşayabileceğini (Öğretir, 2005, s. iii) vurgulamak için kullanırlar. Dolayısıyla "keşif ve aydınlanma anlarını verme aracı" (Öğretir, 2005, s. 82) olan epifanı insanın iç dünyasını aktarmaya yarayan bir anlatı tekniği olarak düşünmek mümkündür. Nitekim bu teknik Koçsoy'un (2018) tespitiyle "anlık tinsel açllımları, varoluşun farkına varıldığı anları ifade etmede sıkça dile getirilmiştir” (s. 116).

Anların anlatı kişisi üzerindeki yoğun etkisi ile şekillenen epifan, kronolojik bir olay örgüsünün söz konusu olmadığı modernist metinlerde "bir düğüm ya da çözüm noktası sağlayarak" (Öğretir, 2005, s. 82) kurgusal geçişleri olanaklı kılar. Lodge’un tespitiyle bu teknik genelde bir hikâye veya bölüme doruk noktasını veya çözülümünü veren geleneksel anlatıdaki belirleyici eylemin yaptığı bir fonksiyona sahiptir (s. 178). Sözgelimi Sanatçının Bir Genç Adam Olarak Portresi”nde "Stephen, bir deneyimden diğerine koşarken, her epifan kendisine yeni bir açılım, yeni bir aydınlık kazandırır ve her bölümün sonunda duygu ve düşünce dizgeleri bir öncekine göre farklılık gösterir" (Öğretir, 2005, s. 18). Epifanı anlatıyı şekillendiren kurgusal kilit noktalarına gönderme yapan bir teknik olarak düşünmek mümkündür.

20. yüzyılın ilk yarısında düşünürlerin geçmişin ve geleceğin ancak insanın bilincinde var olan anımsamalar ve tasarımlardan ve aslında ân'dan ibaret olduğunu ileri sürmeleri modernist romancılarda da yankısını bulur ve aylara yıllara yayılan kurmaca zaman giderek kısalarak olabilecek en kısa zaman dilimine sığdırılır (Apaydın, 2006, s. 18). An odaklı yapısı ile modernist edebiyattaki zaman anlayışı ile de paralellik gösteren epifan, bu tür metinlerde geçmiş ve gelecek arasında bir köprü işlevi görerek anlatıdaki zamansal geçişleri ana toplar. Hayatın özünü zamanda gören, zamanın bir birikim, bir büyüyüp gelişme, bir sürüş olduğunu (Gündoğan, 2010, s. 84) ileri sürerek geçmişin halde belirip geleceği inşa ettiğini savunan Bergson ve Heiddegger gibi düşünürlerin etkisiyle bireyin algıladığı bir zaman anlayışının hâkim olduğu modernist edebiyatta bu teknik, anlatı kişisinin bilincinden geçen anlık aydınlanmaları açığa vurarak iç dünyasına ışık tutar. 
Girift kurgusu ile metnin çözümlenmesi noktasında aktif bir okur kitlesi öngören modernist edebiyatta epifan, "imge ve çağrışımlarla metnin anahtar göndergelerini okura sezdirir" (Koçsoy, 2018, s. 125). Dolayısıyla metnin kilit noktalarına işaret eden bir teknik olarak epifanın anlatı metnini açımlayıcı bir niteliğinin bulunduğunu söylemek mümkündür.

Kısa süren bir yaşam sürecinin birimi olarak anları seçen (Edgü, 1989, s. 12) ve çocukluğundan başlayarak her anı duyup özümseyen (Duru, 1995, s. 146) Tezer Özlü, bunu anlatılarına da sirayet ettiren bir yazardır. Bu çalışmada gerek benimsediği kurgu anlayışıyla gerekse 20. yüzyılda bireyin maruz kaldığı açmaza işaret eden izlekleri ele alışıla modernist yazına eklemlenebilecek bir yazar olduğu anlaşılan Özlü’nün Eski Bahçe (1978), Çocukluğun Soğuk Geceleri (1980) ve Yaşamın Ucuna Yolculuk (1984) adlı üç eserindeki "an”ların işleniş formları kapsamında epifanlar tespit edilerek bu tekniğin modernist anlatıdaki görünümüne ışı tutulmuştur.

Türk edebiyatında epifana ilişkin sayılı çalışmaya ulaşılmış olması çalışmanın ortaya çıkmasındaki temel etkendir. Nitekim literatürde İsmail Öğretir'in (2005) Edebiyatta Epifan Sherwood Anderson'un Winesburg, Ohio'su, Servet Tiken'in (2008) Huzur Romaninda Epifanik Anlar, Gül Koçsoy'un (2018) Küçürek Öyküde Epifan ve Esra Sazyek'in (2019) Ömer Seyfettin’in Hikâyelerinde Epifanik “An”lar adlı çalışmaları dışında konuyla doğrudan bağlantılı başka bir çalışmaya rastlanmamıştır. Konuya ilişkin kimi çalışmalarda 5 ise ya epifana dolaylı olarak yer verildiği ya da Joyce özelinde bir inceleme metodunun tercih edildiği saptanmıştır.

\section{Tezer Özlü’nün eserlerinde “an”ların işleniş formları ve epifanlar}

1950 kuşağının öne çıkan isimlerinden biri olan Tezer Özlü, "yaşamın ve gerçeğin karşılığını kendisiyle ve yazdıklarıyla yaratmaya çalışan” (Oran, 1992, s. 91) bir yazardır. Yazın anlayışı Dostoyevski, Kafka, Tolstoy, Camus gibi dünya edebiyatına damgasını vuran sanatçıların etkisiyle şekillenen Özlü, Türk edebiyatında Ferit Edgü, Leyla Erbil, Sevim Burak, Demir Özlü, Sevgi Soysal, Orhan Duru gibi yazarlara edebî yakınlık duyar. Yetiştiği aile ortamının, depresif ruh halinin, içinde bulunduğu toplumsal, siyasal koşulların ve ömrünün son demlerinde baş etmeye çalıştı̆̆ hastalığının benliğini derinden yaraladığı anlaşılan Özlü'nün, tüm bunlara karşın "yüreğiyle dünyayı kucaklayan, bütün direncini kendi kaynağından alan ve hiçbir zaman yaşamın kıyısında kalmayan bir kişiliği vardır” (Oran, 1992, s. 91). Yazma ereğini "yaşamla ve ölümle hesaplaşmak" (Özlü, 2016e, s. 11) olarak özetleyen yazarın, varoluşunu yazarak gerçekleştirişi (Edgü, 2009, s. 7) ile ölüme adeta meydan okuduğunu söylemek mümkündür.

Modernist edebiyatın bir yansıması olarak büyük ölçüde otobiyografiyi andıran birer kurmaca görünümünde inşa ettiği eserlerinde yaşadıkları acıların akisleri bulunan Özlü, "içsel bir yolculuk" (Uzunhasanoğlu, 2017, s. 22) olarak alımladığı yazının sağaltıcı gücüne inanır. Yeryüzüne dayanabilmek için edebiyatı seçtiğini (Özlü, 2016d, s. 12) dile getiren yazarın kısa süren yazın serüveninden geriye Eski Bahçe (1978), Çocukluğun Soğuk Geceleri (1980) ve Yaşamın Ucuna Yolculuk (1984) adlı üç eseri kalır. Ağabeyi Demir Özlü vasıtasıyla 5o'li yılların hareketli edebiyat ortamına çocuk denecek yaşta giren (Lekesiz, 2001, s. 464) Özlü, edebî hayatına çeşitli dergilerde yayımladığı öyküleri ile atılır. Çeviri

5 İrem Ceren Doğan (2019) James Joyce'un Sanatçının Bir Genç Adam Olarak Portresi Romanım Yazın Çevirisi Stratejileri Açısından Karşllaştırmah İncelenmesi, yüksek lisans tezi; Serdar Odacı (2009) Ulysses ve Tutunamayanlar'da Bilinç Akışı Tekniği, International Periodical For the Languages, Literature and History of Turkish or Turkic Volume 4 /1-I. 605-684; Zennure Köseman (2012) James Joyce'un 'Eveline' ve 'The Boarding House' adh Hikâyelerindeki Ruhsal Çöküntü ve Epifani Gaziantep Üniversitesi Sosyal Bilimler Dergisi 11(2), 587-600; Hasan Baktır, Yiğit Sümbül (2015) Oğuz Atay ve James Joyce’un Modernist Eserlerindeki Aydın Olgusuna Karşılaşttrmah Bir Bakış International Periodical For The Languages, Literature and History of Turkish or Turkic Volume 10/4, p. 851-864. 


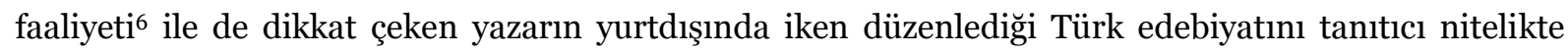
radyo programları ve senaryo çalışmaları da bulunur.

Çalışmanın bu bölümünde Tezer Özlü’nün sağllğında iken yayımlanan Eski Bahçe (1978), Çocukluğun Soğuk Geceleri (1980) ve Yaşamın Ucuna Yolculuk (1984) adlı üç eseri epifan tekniği bağlamında analiz edilmiştir. Yazarın yazdığı öykülerin bir kısmı ölümünün ardından 1987 yılında Eski Sevgi başlı̆̆ı altında ilk öykü kitabına eklenerek Eski Bahçe-Eski Sevgi adıyla yayımlanır; ancak bu öyküler çalışmanın konusu bağlamında incelenmeyi olanaklı kılmadığından örneklem alanına dâhil edilmemiştir.

\section{Eski Bahçe}

Tezer Özlü’nün yazın dünyasına atılışıyla birlikte çeşitli dergilerde yayımladığı öykülerinden oluşan Eski Bahçe (1978); "Dönüş”, “Eski Bahçe”, "Kar”, "Navona Alanı”, "Gabuzzi”, “Amerikalı Komşum Willy”, "Motorcu İbrahim’in Bahçeli Evleri”, "Cafe Boulevard”, "Diskotek Brazil”, "Eski Liman” ve "Hayalet Oğuz" adlı on bir öyküden oluşur. İçerdiği yabancılaşma, yalnızlaşma, varoluşsal bunalımlar ve ölüm gibi izleklerle modernist edebiyatın özü ile uyuştuğu anlaşllan bu öykülerden "Dönüş”, "Eski Bahçe” ve "Kar"da anların belirgin olarak dikkat çektiği görülür.

Otobiyografik bir kurmacanın izdüşümüyle çocukluk döneminin odağa alındı̆̆g “Dönüş”te anlatıcının çocukluk döneminde yaşadığı belirgin anlar adeta bilincine kazınarak tüm yaşamına sirayet eder. Sessizliği, soğukluğu, suyu kurumuş dere yatağı, yıkık mezarlığı (Özlü, 2016a, s. 9) ile çocukluğunun geçtiği kasabanın zihninde ölümü çağrıştırdı ̆̆ı anlatıcı, doğduğu havuz başındaki tahta evde şahit olduğu ölümlerin etkisi altındadır. Özlü'nün çocukluğunda önemli bir yeri olduğu bilinen ninesi Bunni (Sezer, 1992, s. 57) ile otoriter babasının anlatı düzlemine taşındığı öyküde, anlatıcının zihninde anlık olarak uyanan ninesinin ölümü ona ölmüş olan babasını hatırlatır. Babasının bir zamanlar yaptığı büyük masayı (Özlü, 2016a, s. 10) bu ölümü çağrıştıran bir metafor olarak düşünmek mümkündür. Anlatıcının zihninden akan "Masa duruyor. Babam da duruyor. Ben. Masa. Babam. Baba. Ma-Be-Ba” (Özlü, 2016a, s. 11) şeklindeki düşünceler arasında geçen "Ma-Be-Ba" ise sürekli hatırlanan ölüm anına işaret eden bir leitmotiftir. Ölüme meydan okurcasına “ölümleri tatmak istemeyen” (Özlü, 2016a, s. 10); ancak geçmişte yaşadığı anların etkisiyle her gün kendi kendine yeni yeni ölümler hazırlamaktan da (Özlü, 2016a, s. 10) kendini alamayan anlatıcının, doğduğu evin altındaki boşluğa değin uzayan derinlikten başka inandığı hiçbir şey yoktur (Özlü, 2016a, s. 10). Dolayısıyla iç dünyayı şekillendiren anların okura anıştırıldığı öyküde, anın anlatı kişisi üzerinde olumsuz bağlamda bir etki uyandırdığı görülür. Nitekim öyküde yıllarca içinde taşıdığı hayali baba siluetiyle bütünleşip kendini onunla birlikte gömmeyi (Özlü, 2016a, s. 12) zihninden geçiren ve içinde bulunduğu topluma yabancılaşan anlatıcı, çareyi düşlere ve yazıya sı̆̆ınmakta bulur:

Zaman hiç geçmiyor. Hep aynı ince bacaklar. Kafamı yorganın altından çıkaramıyorum. Çıkarırsam düşlerim yok oluyorlar. (Özlü, 2016a, s. 9).

Yorganın altında kalacağım hep. Hep masanın başında oturacağım (Özlü, 2016a, s. 9). Eğleniyorum canım. Gerçekten büyük bir eğlence. Masanın başında otururken ne eğlenceler buluyorum kendi kendime. Eline ufak bir bavul almış. Gitmek üzere. Kafasını sallyyor. O tüm süresini yollarda yitiriyor. Oturduğu zamanlar yazı yazıyor. Veya hiçbir şey yapmıyor. Neler yazdığını bilmiyorum. Kelimeleri art arda diziyor. Herhangi bir sözcüğ̈̈ (Özlü, 2016a, s. 11)

\footnotetext{
$6 \quad$ Ingmar Bergman’n “Yaban Çilekleri” (1965) ile "Aynadaki Sessizlik (1967); Ossip Piatnizki’nin "Bir Bolşeviğin Anıları" (1978) yazarın yaptığı çeviriler arasında yer almaktadır. 
Çocukluk döneminin öne çıktığı "Eski Bahçe", epifanik bir metafor olarak ninenin ölümünü imleyen saklambaç anının anlatıcının yaşamı üzerindeki etkisini içeren bir öyküdür. Öyküde yıllar sonra çocukluğunun geçtiği tahta eve dönen anlatıcı, babası ve ninesi ile oynadığı bu oyun anının zihninde uyandırdığı aksin etkisinde kalır. Bu yönüyle söz konusu anı epifanik bağlamda anlatıcının iç dünyasına şekil veren bir dönüm noktası olarak nitelendirmek mümkündür. Nitekim bu an anlatıcıda ömür boyu sürecek olan bir korkunun tohumudur. Karanlıktan, bir başına oluşundan, uyumaktan, uyanmaktan, çocukluğundan, yaşlılığından korkan (Özlü, 2016a, s. 13-14) anlatıcı, düşüncelerin verdiği korkuyla (Özlü, 2016a, s. 13) sevgilisinden de kaçmaktadır. Ona hitaben sarf ettiği "Bırak beni artık. Bu camdan çırılçıplak aşağıya atlayacağım. Sana karşı değil bu. Çocukluğuma karşı. Bu kente, bu eve, bu halılara, bu değişmeyen her şeye, bu ölmeyen herkese karşı." (Özlü, 2016a, s. 15) şeklindeki cümleleri anlatıcıda çocukluk döneminin travmatik bir anı mahiyeti taşıdığının göstergesidir. "Çocuksu bir duygululuk" (Özlü, 2016a, s. 14) içinde bulunan anlatıcı, "bu tahta eve, bu doğduğum yere . . ne diye gelmiştim?” (Özlü, 2016a, s. 13) "Kaç kez buralara bir daha dönmemek için uzaklara gittim (belki de hiç gitmedim). Hiçbir şey değişmedi” (Özlü, 2016a, s. 14) şeklindeki sözlerinden anlaşılacağı üzere anın etkisinden kurtulamayışının isyanı içindedir. Dolayısıyla öyküde tüm yaşamını kuşatan o anı bastırma çabası içinde olduğu sezilen anlatıcı, geçmişi ile bir hesaplaşma içindedir. Epifanik düzlemde otobiyografik kurmaca yönü ağır basan bu öyküyü bir bakıma Özlü’nün “çocukluk günlerine neşter vurma isteği”nin (Darılmaz, 2011, s. 17) bir dışavurumu olarak değerlendirmek mümkündür.

Bir düşle başlayan "Kar", bu düş içerisindeki epifanik bir metaforla okurun anlatı kişisinin çocukluk dönemiyle buluşturulduğu bir öyküdür. Düşünde çocukluğunun geçtiği evde ışık vermeyen, parlak mumların ufak alevleri arasında birden bire çoğalan fareler gören (Özlü, 2016a, s. 17) anlatıcı, korkuyla çocukluk anılarına geri döner. Epifanik bağlamda öyküde tüm yaşamı kuşatıcı etkisiyle bir dügü̈m noktası niteliği taşıdığı anlaşılan düş anındaki "fare", çocukluk döneminde yüzleşilen ölüm korkusunu imleyen bir metafordur. Gördüğü düşün ardından zihninde aynı odayı paylaştığı ninesinin ölüm döşeğinde uzun süre yattığı anlar, karnına dayadığı bıçakla kendini öldürme girişimi ve cenaze merasimi canlanan anlatıcının iç dünyasında ölümle bir çatışma hali içinde olduğu sezilir. Epifan anının anlatı kişisi üzerinde olumsuz bir etki yarattığı anlaşllan öyküde, ölümünü anlamadan büyüdüğünü (Özlü, 2016a, s. 20) dile getiren anlatıcının "yüksek bir evin balkonunda tek koluyla asılı kalma" (Özlü, 2016a, s. 20) sanrısı, bu çatışmanın bir izdüşümüdür. İzleksel dokusu itibariyle bu öykü, otobiyografik bağlamda yazma edimi büyük ölçüde yaşam ile ölüm arasındaki hesaplaşma ile şekil alan Özlü'nün yazınsal tutumu ile de örtüşür.

\section{Çocukluğun Soğuk Geceleri}

Tezer Özlü’nün ilk romanı Çocukluğun Soğuk Geceleri (1980), çocukluk ve ilk gençlik döneminde insanın iç dünyasında yaşadığı dramı dillendiren otobiyografik kurmaca nitelikli bir anlatıdır. Özlü’nün yaşamından izler taşıyan anlatıya kurmaca birer karakter olarak yazarın yakın çevresinin konuk edildiği görülür. "Ev", “Okul ve Okul Yolu”, “Leo Ferre’nin Konseri” ve "Yeniden Akdeniz” adlı dört bölümden oluşan romanda çocukluk bilançosunu yazarlık bilinciyle yoğurmaya çalışan bir yazar (Hızlan, 1986, s. 69) olarak karşımıza çıkan Özlü, uyguladığı modernist anlatı tekniğiyle okuru otobiyografi ile kurmacanın sınırlarında dolaştırır. Bu bağlamda İplikçi’nin (2012) şu cümleleri romanın bu yönüne işaret etmektedir:

Gelenekseli sorgulayan bir metindi bu. Metne ister otobiyografik bir eser olarak bakalım, ister bakmayalım (her metin bir otobiyografi olabilir; öte yandan otobiyografi olanlar da birer öykü olarak okunabilir) benim açımdan varılacak yer belliydi: Bir yapıbozum! Ben'in deşifresi. Ben'i kurgulayanın ifşa edilmesi. Ben’in yarattığı anlamın, anlamın yarattığı benden farklı olduğunun gösterilmesi (s. 5). 
Çocukluğun Soğuk Geceleri anların anlatı kişisinin yaşamı üzerindeki etkisinin sergilendiği bir anlatıdır. Şahin’in (2018) ifadesiyle andan geçmişe yolculuğun söz konusu olduğu eserde geçişler alabildiğine hızlıdır ve yazar geçmişe giderken günü yani yaşadığı ânı da sorgular (s. 660). Dolayısıyla romanda anlar aracılı̆̆ıyla kurgusal geçişler sağlanır. Şahin’in (2018) bu geçişleri bir sinema filmine benzettiği görülür:

Özlü’nün eserinde . . . anların istiflenişi sanki bir sinema filmini andırır. Çocukluğun Soğuk Geceleri kitabında anılara kamera tutulur. Kamera, küçük bir kız çocuğunun olgun bir kadına dönüşüne tanıklık eder . . . Kamera olanları gösterir, oysa romanda ya da başka anlatılarda okurdan da beklenenler vardır; bazen okurun kurguda bağlantılar yakalaması istenir. Tezer Özlü ise kâh getirdiği eleştiriyle kâh "insan ruhu"nu aradığı/sorguladığı samimiyetinde okuru, kendi okurunu bulmak ister; sinemadaki kamera hızıyla romantik söylemden gerçekliğe hareket eder ve okur da o anlara tanık olur. Okuru sarsar, şaşırtır. Kendi yaşadı̆̆ı sarsıntıya okuru ortak eder (s. 667).

Özlü’nün çocukluk yıllarından akisler taşıyan birinci bölümde bir değişime yol açarak anlatı kişisini evden uzaklaştıran ve onu "gitmek"e sevk eden etken çocukluk dönemindeki kimi anlardır. Çocukluğu "eski, anılarla dolu, küf kokan, merdivenleri karanlık, nemli ve soğuk bir evde” (Özlü, 2014, s. 16) geçen anlatıcı, gündelik hayatındaki söz konusu anların olumsuz etkisiyle "dışarıda, yaşamın gürültüsü içinde, ya da başka evlerde, başka insanlarla yaşama” (Özlü, 2014, s. 15) arzusu duyar. Anlatıcının bir zamanlar beden eğitimi öğretmenliği yapmış olan babasının sabahları düdüğünü öttürerek ev halkını uyandırma (Özlü, 2014, s. 7), geceleri hem soğuktan hem de yalnızlıktan korunmak için annesine sokulma (Özlü, 2014, s. 8), seyahat eden, büyük kentlere gidip gelen insanlara özlemle bakma (Özlü, 2014, s. 8), Bunni ile buz gibi bir banyoda yıkanma (Özlü, 2014, s. 9) anları romanda bu türden anlar arasında yer alır. Aşağıdaki pasaj okura anın anlatı kişisi üzerindeki çarpıcı etkisini özetleyen bir açılım sunması ile dikkati çekmektedir:

Pazar günleri... Şimdilerde... Sokak aralarından geçerken... gözüme pijamalı aile babaları ilişirse, kışın, yağmurlu gri günlerde tüten soba bacalarına ilişirse gözlerim... evlerin pencere camları buharlaşmışsa... odaların içine asılmış çamaşır görürsem... bulutlar ıslak kiremitlere yakınsa, yağmur çiseliyorsa, radyolardan naklen futbol maçları yayımlanıyorsa, tartışan insanların sesleri sokaklara dek yansiyorsa, gitmek, gitmek, gitmek, gitmek, gitmek........ isterim hep (Özlü, 2014, s. 16).

Anlatının "Okul ve Okul Yolu” bölümü anlatıcının çocukluk ve gençlik yılları üzerine kuruludur. Özlü’nün yaşamından izler taşıdığı anlaşlan bu bölümde okur, anlatı kişisinin yaşadığı epifanik bir an aracılı̆̆ıyla geçmişle hesaplaşmasına tanık olur. Romanda bir an önünde uzayan, gri mavi Marmara denizine uzun süre bakıp içindeki kıpırdanışları dinlerken bir şeylere açılmak, bir yerlere koşmak, dünyayı kavramak isteyen ve dünyanın ona yaşatılandan öğretilenden daha başka olduğunu sezen anlatıcı, o yıllarda o kaygılara çözüm getirecek hiçbir olgunun olmadığını (Özlü, 2014, s. 25) anlar. Denizdeki gri maviliğin anlatı kişisine "uzun, ıslak, nemli, soğuk gri yıllar" (Özlü, 2014, s. 29) addettiği çocukluk ve ilk gençlik dönemini anımsattığı romanda, deniz anlatı kişisinin iç dünyasını harekete geçiren epifanik bir metafordur. Çocukluğuna öğretmen anne babanın, Müslüman mahallelerindeki dar evlerin, kilise okulunun Katolik havasının, düşünceleriyle bağdaşmayan çılgın sayılacak rahibelerin yarattığı bir sıkıntının (Özlü, 2014, s. 22) hâkim olduğu anlatıcı, yaşamın anlaşılmaktan ziyade yaşanması gerektiğini duyumsayarak dış dünyaya yönelir. Ona göre güzel ve gerçek olan, kentin insanları, kalabalık ve dış dünyanın insanın kulaklarına varan uğultusudur (Özlü, 2014, s. 23). "Şimdi o ilerilere itilen, gelecekteki yaşamın içindeyim" (Özlü, 2014, s. 23) sözlerinden yetişkinlik döneminde olduğu anlaşılan anlatıcı, İstanbul sokaklarının hengâmesinden hoşnuttur. Romanın birinci bölümündeki anlar, zamansal bir sürecin ürünü olarak kurmaca karakterin gelecek yaşamı üzerindeki aksine işaret ederken ikinci bölümünde sözü edilen an epifan niteliği taşır ve anlatıcının yaşamı üzerinde bir düğüm noktası işlevi görür. 
Anlatının "Leo Ferre'nin Konseri” adlı üçüncü bölümü genel olarak anlatıcının bir Avrupa şehri ile İstanbul izlenimlerinden, depresif sorunları dolayısıyla yatırıldı̆̆ı klinik anılarından ve evlilik hayatından kesitler taşır. Modernist yazınla paralel olarak kronolojik bir olay örgüsüne rastlanmayan romanda bu türden kesitlerin anlatının çeşitli yerlerine serpiştirildiği görülür. Öz yaşamında anları önemseyen bir yazar olan Özlü’nün bu yönünün anlatıda bir yazar olduğu anlaşılan kurmaca karakterin yazınsal tutumunda aksini bulduğu ve bu bağlamda epifanik anların vurgulandığı görülür. Epifanın düşünsel dayanağı ile paralel olarak yaşamın her zaman günlük hareketliliklerini yeğleyen kurmaca yazar, kısacık anlarda çeşitli olayları, insan varoluşunun özünü, zaman ve duyguları sınırsızlık içinde derinliğine düşünür (Özlü, 2014, s. 33). Ona göre "bir an, zamanları, olayları, duyguları . . . aşan olaylarla dolu”dur (Özlü, 2014, s. 33). Anlatı kişisinin Leo Ferre konserinde yanında oturduğu gençle gittikleri kahvede birden eski eşini hatırlaması bu türden bir andır. Onu kaybedişinin üzerinden iki sonbahar geçen anlatıcı, Paris’in Select kahvesinde başlayan, Şişli’nin bir özel sinir kliniğinde biten beraberliğini uzun yaşamın bir küçük kesiti (Özlü, 2014, s. 57) addeder. Anlatıcının onunla birlikte hiçbir şeyinin ölmediğini (Özlü, 2014, s. 57) dile getirmesi tüm acılarına karşın içinde taşıdığı yaşama sevincinin bir ifadesidir. Bu bağlamda onun sarı, turuncu sonbahar yapraklarından gelen doğa kokusunu o zamana dek algıladığı en güzel koku olarak duyması (Özlü, 2014, s. 57) kayda değerdir. Dolayısıyla romanda anlatıcının iç dünyasında yaşadığı aydınlanma anı epifan tekniği ile okura yansıtılır.

Romanın "Yeniden Akdeniz" başlıklı son bölümünde anlatıcı bir Akdeniz köyündedir. Bir önceki bölümdeki epifan anının etkisiyle bu köyde doğanın uyanışını tüm benliğinde duyumsayan anlatıcının doğanın güzelliği karşısında büyülendiği, "doyumsuz yaşamı kucaklama isteği” (Özlü, 2014, s. 60) ile anı yaşadığı; ancak ölümü de yaşam kadar olağan karşıladığı görülür. Ona göre insan sevgilerini de yaşamı da güzel uğurlamalıdır (Özlü, 2014, s. 61). İstanbul'a döndüğünde kasvetli bir ortamla karşılaşan anlatıcı yaşamın güzelliğini kentin alelade görünümünde, "bir masal dünyası" (Özlü, 2014, s. 63) addettiği doğada ve iki insanın sarıldığı anda bulur. Otobiyografik bir kurmaca ile anlatı kişisinin aydınlanma anlarına yer verilen romanda anların insan yaşamı üzerindeki etkisinin dillendirildiği görülür. "Acıyla, yalnızlıkla, ama aynı zamanda coşkuyla, aşkla dolu anlarını, anlarının anılarını yazan” (Özlü, 2016b, s. 7) bir yazar olarak Özlü’nün, otobiyografik bir kurmaca görünümünde kurguladığı anlatısında epifanlar aracılığıyla kendi iç dünyasına ilişkin ipuçlarını da okurla buluşturduğunu söylemek mümkündür.

\section{Yaşamın Ucuna Yolculuk}

Tezer Özlü’nün 1984 yllında yayımlanan ikinci romanı Yaşamın Ucuna Yolculuk, yazarın 1983’te Almanca olarak yayımladığı "Auf dem Spur eines Selbsmords" (Bir İntiharı İzinde) adlı romanının çevirisidir. 1983 Marburg Yazın Ödülü’nü alan roman, Özlü’nün ilk romanı ile benzer olarak otobiyografik kurmaca nitelikli bir anlatıdır. Roman yazarın önemsediği üç yazar olan Kafka, Svevo ve Pavese'nin izini sürmek üzere çıktığı yolculuğun izlenimlerinden oluşur. Özlü ilk kez düşüncelerini en derin uçlarına dek izleyebilme olanağını bulduğunu (Özlü, 2016c, s. 33) ifade ettiği Berlin'de iken yazmaya başladığı romanının üçte ikisini Berlin-Prag-Viyana-Zagreb-Belgrad-Niş-Belgrad-ZagrebTrieste-Torino-S. Stefano Belbo arasındaki yedi bin kilometrelik yolda on gün içinde trenlerde, istasyonlarda ve otellerde (Özlü, 2016e, s. 114) tamamlar. "Yol onun hem yaşamını hem edebiyatını derinden belirleyen bir izlek”tir (Karakaşlı, 2012, s. 10).

Anlatı kişisinin yaşadığı bir epifan anı ile başlayan Yaşamın Ucuna Yolculuk, söz konusu anın anlatının bütününe yön verdiği bir anlatıdır. Romanda bir süre sinir hastanesinde kaldığı ve kaybettiklerinin yasını tuttuğu anlaşılan anlatıcı, Berlin'de yılın bir ilkbahar gününde Pavese ile aynı gün doğduğunu öğrenir. Anlatıcı evinin gökyüzüne açık bir hücreyi anımsatan balkonunda otururken Berlin 
sokaklarının, Pazar günlerinin bırakılmışlığında esen rüzgârı tenine değdiğinde birdenbire o zamana dek hiç algılamadığı bir duygu olan bırakılmışlığın tadını duyumsar ve artık acıları mutluluk olarak nitelendirmeye karar verir (Özlü, 2016d, s. 10). Yaşam ile ölüm arasındaki girdapta "insanın birbaşınalığının çaresizliğini” (Özlü, 2016d, s. 11) kanıksayan anlatıcının, bu duygu ile ölümü de kabullendiği görülür. Romanda söz konusu epifan anı bir bakıma anlatıcının iç dünyasında bir eşik noktası yaratır. Anlatıcının Kafka, Svevo ve Pavese'nin izini sürmek üzere çıktığı yolculuk bu eşiğin bir izdüşümüdür. Dolayısıyla romanda epifan, anlatının düğüm noktasında belirleyici bir rol oynayan bir teknik olarak dikkati çekmektedir. Anlık her görüntüyü yaşantıya dönüştürerek yaşamı büyütme, kendince geliştirme, derinleştirme (Özlü, 2016d, s. 33) çabası içinde olan anlatıcının ilk durağı Kafka'nın mezarının bulunduğu Prag'dır. Yaşanılan her anın geçmişin ağır anılarıyla güçleştiğini (Özlü, 2016d, s. 35) düşünen anlatıcı, yazarın mezarı başında iken hafiflediğini hisseder. Anlatıcı için Prag'da geçirdiği bir tek gün yaşamının birçok mevsiminden daha yoğundur (Özlü, 2016d, s. 50).

Romanda bırakılmışlı̆̆ın tadını duyumsadığı epifan anından önce gidememenin kendisinde derin bir acı uyandırdığı anlatıcı, yaşadığı aydınlanma anı ile yaşamı GİTMEK olarak algılamaya (Özlü, 2016d, s. 39) başlar. Berlin-Hamburg-Berlin, Batı-Doğu-Prag-Viyana hattı boyunca ilerlediği yolculukta Niş kentinde duraklayan anlatıcının iç dünyası ile bir hesaplaşma içine girdiği ve acılarını sözcüklere dönüştürme (Özlü, 2016d, s. 44) çabasıyla yazarların dünyasına sı̆̆ındı̆̆ı görülür. Ona göre edebiyat yaşam ve ölümün sınırlarının artık acıları tutamadığı, tutmaya yeterli olmadığı yerde başlar (Özlü, 2016d, s. 83).

Romanda toplumla uyuşamadığı anlaşılan anlatıcının, kaldığı otelin terasında doyumsuz bulutların sonsuzluğunu düşünürken birden içinde her şeyin değişeceğine dair bir umut uyandığı (Özlü, 2016d, s. 59) ve bu anın etkisiyle İtalo Svevo'nun izini sürmek üzere Trieste’ye gitmeye karar verdiği görülür. İç dünyasında anın yoğunluğunu (Özlü, 2016d, s. 73) duyumsayan anlatıcı, yaşadığı sıradan anlardan hareketle çıktığı yolculukları da dünyalara açılan yeni yaşamlar (Özlü, 2016d, s. 66) addeder. Svevo ile kendi yaşamı arasında bağlantı kuran anlatıcının Svevo'nun kızı Letizia'nın “GERİ KALAN YALNIZ BOŞLUKLAR, İNSAN YALNIZ” (Özlü, 2016d, s. 88) şeklindeki sözleri ile yalnızlı̆̆ıyla yüzleştiği ve yaşamına yeni bir yol çizdiği görülür. Pavese'nin izini sürmek üzere Torino yönünde trenle ilerlerken anlatıcının zihninden akan şu düşünceler “an” değiştirici/dönüştürücü etkisini yansıtması ile dikkati çekmektedir:

Yalnız kalmayı yeğliyorum, diyorum.

(ilk kez bu tümceyi söyleyebildiğime şaşıyorum. Artık ilk kez kendi kendime olmak istediğimden, bir başka insana, insana hiç dayanacak gücüm yok. Belbo tepelerinde bundan böyle dağlarla, tepelerle, sularla, göllerle, denizlerle, nehirlerle, ağaçlarla, rüzgârlarla, yağmurlarla, gecelerle, günlerle, bulutlarla, gökyüzü ve yıldızlarla yaşamaya karar vermiş olacağım) (Özlü, 2016d, s. 96).

Anlatıcı son durağı olan Torino'da ise Pavese'nin intihar ettiği otel odasına giderek ölümle yüzleşir. Romanda anlatıcının içinden geçen "İntiharı algılıyorum . . . O varlı̆̆ımı bürüyor. Varlığımın tüm zaman ve zamansızlığını. Sonsuz intiharı bürüyor beni . . İş̧e ölüm burada. Ölümün her çeşidi” şeklindeki düşünceler bu yüzleşmeyi birebir açığa vurmaktadır. "Geçmişini anında taşıyan bir kadın” (Özlü, 2016d, s. 108) olarak yaşama karşı olan açlı̆̆ını doyurmak üzere bütün yaşama cesaretini bizzat ölülerden (Özlü, 2016d, s. 80) alan anlatıcı, yaşamla birlikte ölümü de kanıksar. Anlatıcının zihninden geçen "her yirmi dört saat, hem yaşam, hem ölüm. Ve ilk kez bu yolculuğum süresince, yazarlarımın çevrelerinde, sokaklarında, kahvelerinde, bulvarlarında, mezarlarında, evlerinde, dünyaya baktıkları yörelerde çıktığım bu yolculukta, içimde sürekli çakışan ikili kişiliğin, tek bir 'ben'de birleştiğini sezinliyorum" (Özlü, 2016d, s. 121) şeklindeki düşünceler bunu açığa vurmaktadır. Dolayısıyla romanda anlatıcının 
yaşam ile ölüm arasındaki çatışmayı dengelemesine neden olan "an"ların anlatı kişisinin iç dünyasında olumlu yönde bir değişime neden olduğunu söylemek mümkündür. Romanda söz konusu edilen çatışmayı Özlü de bir yazar olarak bizzat yaşamıştır. Daha küçükken ışı̆̆ın arkasına saklanmış ölümün gölgesini gören (Önal, 2016, s. 120) Özlü, yazarak bu çatışmayı yenmiştir.

\section{Sonuç}

Tezer Özlü'nün Eski Bahçe, Çocukluğun Soğuk Geceleri ve Yaşamın Ucuna Yolculuk adlı üç eserinin analiz edildiği bu çalışmada yazarın yalnızca üç öyküsünde anların belirgin olarak dikkat çektiği ve bu öykülerden ikisinde rastlanan epifanın romanlarında kullanım sıklığının arttığı tespit edilmiştir.

Yazarın ölüm ile çocukluğun belirgin iki izlek olarak öne çıtığı iki öyküsünde epifanik anların büyük ölçüde çocukluk döneminde yoğunlaştığı dikkati çekmiştir. Söz konusu öykülerde kurmaca karakterlerin imgeleminde gerçekleşen zihinsel uyanışların ve çocukluk, gençlik, yaşlılık arasındaki zamansal geçişlerin epifanlar aracılığıyla sağlandığı görülmüştür.

Çalışmada Özlü’nün romanlarında epifanın insanın iç dünyasını yansıtmak ve akronolojik kurgunun seyrine şekil vermek için yer yer kullanılan bir anlatı tekniği olduğu anlaşılmıştır. Romanlarda epifanlar aracıllğıyla okura anlatı kişilerinin geçmiş yaşamları ile hesaplaşmaları yansıtılmıştır.

Özlü’nün eserleri üzerine yapılan incelemeden hareketle epifanın anlatı kişilerinin ruhsal dünyalarının analizini olanaklı kılan bir teknik olduğu ve okurun insanın iç dünyasına ilişkin ipuçları barındıran bu teknik aracılığıyla bireyin içsel serüvenine tanık edildiği sonucuna ulaşılmıştır. Batı'daki gelişmeleri yakından takip eden bir yazar olduğu anlaşılan Özlü’nün otobiyografik birer modernist kurmaca olarak kurguladığı anlatılarında epifanı kendi iç dünyasını yansıtmak için bir araç olarak kullandığı saptanmıştır. Dolayısıyla epifan hem kurgusal dünyadaki anlatı kişilerinin hem de bizzat yazarın iç dünyasına ışık tutan bir anlatı tekniğidir.

\section{Kaynakça}

Apaydın, M. (2006). "Adalet Ağaoğlu'nun Dar zamanlar üçlemesinde zaman kurgusu üzerinde bazı değerlendirmeler” Ç.Ü. Sosyal Bilimler Enstitüsü Dergisi, 15/2 s.17-38.

Apaydın, M. (2020). "Güvenilmez anlatıcı tipolojisi ve Anayurt Oteli’nin güvenilmez anlatıcısı hakkında bazı değerlendirmeler” Roman Kahramanları, 41, s. 142-154.

Ballard, E. (2012). Epifani hayat değiştiren anlar. (S. Demirci, Çev.). İstanbul: Kuraldışı.

Can, Ş. (1970). Klasik Yunan Mitolojisi. İstanbul: İnkılap ve Aka Kitapevleri.

Darılmaz, M. (2011). "Eski bahçe-Eski sevgi Tezer Özlü öykülerinin izlekleri” Öykü Teknesi, 19, s. 16-18.

Duru, S. (1995). “Ancak çok sık gördüğümü ya da ölenleri özlüyorum”. Tezer Özlü’ye armağan içinde (s. 146-148). İstanbul: YKY.

Duru, S. (2015). Tezer Özlü’ye armağan. İstanbul: YKY.

Edgü, F. (1989). “Önsöz yerine Tezer’den kalanlar”. Kalanlar içinde (s. 7-12). İstanbul: YKY.

Edgü, F. (2009). Önsöz. "Her Şeyin Sonundayım” Tezer Özlü-Ferit Edgü mektuplaşmaları içinde (s. 79). İstanbul: Sel.

Gündoğan, A. O. (2010). Bergson. Ankara: Say.

Hızlan, D. (1986). “Tezer Özlü için”. Tezer Özlü’ye armağan içinde (s. 69-70). İstanbul: YKY.

İplikçi, M. (2012). “Çocukluğun soğuk geceleri”ndeki ben’e bakış” Varlık Aylık Edebiyat ve Kültür Dergisi, 1252, s. 4-5. 
Joyce, J. (1996). Epiphanies/anıkhklar. (L. Kavas, Çev.) İstanbul: Altıkırkbeş.

Karakaşlı, N. (2012). "Tezer Özlü’nün yolları: Gitmenin getirdikleri” Varlık Ayllk Edebiyat ve Kültür Dergisi, 1252, s. 10-19.

Koçsoy, G. (2018). “Küçürek öyküde epifan” Humanitas International Journal of Social Sciences, 6(11), S. $115-127$

Lekesiz, Ö. (2001). Yeni Türk edebiyatında öykü. C. 4, İstanbul: Kaknüs.

LONGMAN Dictionary of contemporary English (2010). Pearson Education Limited.

Lodge, D. (2013). Kurgu sanatı. (A. Ören, Çev.). Ankara: Hece.

Oran, F. (1992). "Seni çok özlüyoruz Tezer Özlü”. Tezer Özlü’ye armağan içinde (s. 90-92). İstanbul: YKY.

Öğretir, İ. (2005). Edebiyatta epifan Sherwood Anderson'un Winesburg, Ohio'su. Konya: Çizgi Kitabevi.

Önal, B. (2016). “Ölümün sevgili yazarı: Tezer Özlü” Kitap-lık, 184, s. 117-123.

Özlü, T.; Edgü, F. (2010). "Her şeyin sonundayım” Tezer Özlü- Ferit Edgü mektuplaşmaları. (B. Fidan, yay. haz.) İstanbul: Sel Yayıncllı.

Özlü, T. (2014). Çocukluğun soğuk geceleri. İstanbul: YKY.

Özlü, T. (2016a). Eski bahçe- Eski sevgi. İstanbul: YKY.

Özlü, T. (2016b). Kalanlar. M. Yalçın (Ed.). İstanbul: YKY.

Özlü, T.; Erbil, L. (2016c). Tezer Özlü'den Leyla Erbil'e mektuplar (L. Erbil, yay. haz.) İstanbul: YKY.

Özlü, T. (2016d). Yaşamm ucuna yolculuk. İstanbul: YKY.

Özlü, T. (2016e). Yeryüzüne dayanabilmek için. (S. Duru, yay. haz.) İstanbul: YKY.

Sazyek, H. (2013). Roman terimleri sözlüğ̈̈̈. Ankara: Hece.

Sazyek, E. (2019). “Ömer Seyfettin'in hikâyelerinde epifanik "an"lar" Hece Aylık Edebiyat Dergisi, Hikâyenin Türkçe Sesi Ömer Seyfettin Özel Sayısı, 265, s. 75-92

Sezer, S. (1992). “Tezer Özlü’nün dünyası”. Tezer Özlü’ye armağan içinde (s. 56-60). İstanbul: YKY.

Şahin, H. (2018). "Sinematografik bir anlatım örneği: Tezer Özlü'nün çocukluğun soğuk geceleri adlı kitabı" Turkish Studies, 13/3, s. 659-672.

TDK Türkçe sözlük. (2005). Ankara: Türk Dil Kurumu.

Tiken, S. (2008). "Huzur romanında epifanik anlar” Türkoloji Kültürü.C.1., N.1, s. 51-63.

Tunç, A. (2017). “Tezer Özlü ile sarsıcı bir okuma serüveni” Arka Kapak, 24, s. 26-27.

Uzunhasanoğlu, İ. (2017). "Yaşamın ucundaki kadın" Arka Kapak, 24, s. 22-23.

https://tureng.com/tr/turkce-ingilizce/magi.(Erişim Tarihi: 05.07.2020). 